\title{
O DISPOSITIVO DA COLONIALIDADE DE GÊNERO NO DISCURSO TRANSFÓBICO ONLINE
}

\section{THE DEVICE OF GENDER COLONIALITY IN ONLINE TRANSPHOBIC DISCOURSE}

Danillo da Conceição Pereira Silva'

\begin{abstract}
RESUMO: Neste artigo, proponho a compreensâo da violência linguística praticada contra pessoas trans enquanto instância do dispositivo de colonialidade de gênero vigente na sociedade brasileira. Para tanto, orientado por perspectivas pragmáticas e socioantropológicas da linguagem acerca das noçōes de performatividade, violência linguística, indexicalidade e entextualizaçăo, articulo construtos teóricos sobre as problemáticas da colonialidade/decolonizaçấo do mundo ocidental eurocentrado com as discussōes sobre performances de gênero, vivências trans e transfobia, informadas por perspectivas queer/cuir/transviadas dos estudos das dissidências sexuais e de gênero. Do ponto de vista analítico, discuto dados gerados em uma pesquisa de cunho etnográficovirtual, realizada entre junho de 2015 e junho de 2016, na seçâo de comentários online do site de notícias brasileiro G1, a partir de interaçóes acerca de matérias que tematizam a crucificaçâo encenada pela atriz e modelotransexualVivianyBeleboni, durantea 19 a Parada do Orgulho LGBT de Săo Paulo, ocorrida em 2015. Ao cabo do trabalho, argumento, grosso modo, que o dispositivo da colonialidade de gênero assenta seu horizonte simbólico em marcos de reconhecimento que significam como violentáveis, matáveis e disciplinarmente puníveis sujeitos cujas performances de gênero estăo em desacordo com ontologias coloniais fundadas na alegada coerência compulsória entre sexo, gênero e desejo.
\end{abstract}

PALAVRAS-CHAVE: Violência linguística. Colonialidade de gênero. Transfobia. Indexicalidade. Entextualização.

ABSTRACT: In this article, I propose the understanding of the linguistic violence practiced against trans people as an instance of the device of gender coloniality prevailing in Brazilian society. To do so, guided by pragmatic and socioanthropological perspectives of language about the notions of performativity, linguistic violence, indexicality and entextualization, I articulate theoretical constructs regarding the issues of coloniality/ decolonization of the eurocentred western world with discussions on gender performances, tran experiences and transphobia, informed by queer perspectives on studies of sexual and gender disagreements. From an analytical point of view, I discuss data generated in an ethnographic research conducted between June 2015 and June 2016, in the online

1 Professor de Língua Portuguesa do Instituto Federal de Educaçáo, Ciência e Tecnologia de Alagoas (IFAL), campus Santana do Ipanema. Doutorando em Letras/Estudos Linguísticos pelo Programa de PósGraduaçăo em Letras da Universidade Federal de Sergipe (PPGL/UFS). E-mail: danillosh@gmail.com. 
comments section of the Brazilian news site $\mathrm{Gl}$, based on interactions that address the crucifixion which was staged by the actress and transsexual model Viviany Beleboni during the 19th Sâo Paulo LGBT Pride Parade, held in 2015. In the end, I argue, broadly speaking, that the device of gender coloniality rests its symbolic horizon in landmarks of recognition that signify as violable, killable and disciplinarily punishable subjects whose performances of gender are in disagreement with colonial ontologies founded on the alleged compulsory coherence between sex, gender and desire.

KEYWORDS: Linguistic violence. Gender coloniality. Transphobia. Indexicality. Entextualization.

\section{PALAVRAS INICIAIS}

Enquanto escrevia este artigo, dentre tantos textos que me atravessavam nesse processo, vindos de diferentes lugares, alguns em particular pareciam se precipitar sobre os sentidos que aqui procurava produzir, sobre os termos da argumentaçấo que construía em torno da violência linguística de motivaçăo transfóbica enquanto dispositivo da colonialidade de gênero. Eram narrativas noticiosas, comentários em redes sociais digitais, diálogos com pessoas queridas da academia e de fora dela, múltiplas semioses em trânsito sobre um mesmo evento. Nesse fluxo, um texto, em específico, viajou até mim de forma insistente, por um lado, açoitando minha sensibilidade política e ativista e, por outro, despertando aquela boa e sempre nova atençáo etnográfica, enquanto linguista aplicado. Eis aí sua recontextualizaçâo:

[...] se um homem nasce homem e se sente mulher, daqui a cinquenta, cem anos, duzentos anos, se for encontrado um osso dele e for estudado pela medicina, vai constatar que veio de um homem, portanto, senhor presidente e caros pares aqui presentes, nós estamos falando de uma questăo de equidade biológica [...] e năo apenas esse tipo de descalabro que vem acontecendo no nosso estado, no nosso país, como eu já vi em muitos banheiros no centro cultural Sáo Paulo, um absurdo, escrito lá, esse banheiro é de homens cis, homens trans, homens năo sei das quantas, homens daquilo outros, e nos das mulheres exatamente a mesma coisa, mulher cis, mulheres trans, mulheres sei lá sabe o que... a populaçăo brasileira assim como resto do mundo nasce homem ou mulher, com total respeito, você pode fazer o que você quiser da sua vida, você pode ser mulher, você pode ser homem, você pode ser travesti, você pode ser trans, năo interessa pra mim [...] mas você precisa sim respeitar os valores do nosso povo, respeitar principalmente a própria biologia, porque, senhor presidente, com todo respeito, se acaso dentro do banheiro de uma mulher em que a minha irmá ou a minha máe estiver utilizando e entrar um homem que se sente mulher ou que pode ter arrancado o que ele quiser, colocado o que ele quiser, porém eu năo estou nem aí... se um homem que se acha mulher entrar no banheiro em que estiver minha mâe ou minha irmá, tiro o homem de lá a tapas e depois chamo a polícia, é esse o ponto que chegou no nosso Brasil, é esse o ponto que chegou no nosso estado de Săo Paulo (GARCIA, 2019, s/p)².

2 Uma vez que tal citaçấo cumpre funçăo ilustrativa neste artigo, năo sendo meu objetivo realizar uma análise detalhada dela, nem tampouco observar aspectos fonológicos, prosódicos ou conversacionais de tal enunciado, optei por uma transcriçâo textual, sem indicaçâo específica desses aspectos, sinalizando apenas os recortes efetuados com o uso das reticências entre travessóes. 
Essa é a parte linguística da combinaçăo multissemiótica de um ato de fala que, para além de representar ou descrever uma dada realidade, a produz. Ou seja, performa via linguagem a violência transfóbica, mediante a entextualizaçăo (BAUMAN; BRIGGS, 2006) de discursos que circulam em outras práticas de linguagem, para além do "aqui" e do "agora" interacionais, para além do contexto de ocorrência. Discursos esses que evocam e que sâo arregimentados pela ordem dos saberes-poderes (FOUCAULT, 2009) médico-científicos acerca da suposta evidência biológica do gênero dimórfico, inscrita no corpo, e de um suposto "respeito à diferença", à diferença que confortavelmente se assimila e que năo possui agência política, que respeita a biologia politizada dos essencialistas e "os valores do nosso povo". "Povo", aqui, funciona como uma pista indexical que mobiliza os sentidos de uma categoria da qual as pessoas trans ${ }^{3}$ certamente náo participam, uma vez excluídas da esfera cidadă, inclusive pela inter diçăo de existirem, especialmente em espaços públicos e de decisăo política, a exemplo daquele onde tal caso de violência linguística se desenrolou.

O discurso anteriormente citado, em destaque, corresponde à fala do deputado estadual Douglas Garcia, do Partido Social Liberal (PSL), desferida contra a deputada Érica Malunguinho, do Partido Socialismo e Liberdade (PSOL), pessoa trans negra, nordestina, educadora, ativista, agente cultural e primeira a ocupar tal funçăo pública em 180 anos de existência da Assembleia Legislativa do Estado de Săo Paulo (ALESP). A projeçăo de signos que subalternizam, desqualificam e deslegitimam pessoas trans, posicionando-as em um lugar abjeto, a exemplo da aqui transcrita, foi proferida após uma intervençăo da deputada supracitada, em sessâo plenária no dia 04 de abril de 2019, na qual denunciava o teor também transfóbico do Projeto de Lei n³46/2019, de autoria do deputado Altair Gomes, do Partido Republicano do Brasil (PRB), em tramitaçăo naquela casa. Tal projeto propóe estabelecer o sexo biológico como único critério válido para definiçăo do gênero em partidas esportivas oficiais no Estado de Sáo Paulo, face à polêmica transfóbica de longa duraçâo criada em torno da presença de pessoas trans em competiçōes esportivas, já bastante ventilada na mídia nacional.

Certamente, os marcos normativos de reconhecimento simbólico nos quais se apoia a violência transfóbica realizada pelo pronunciamento do deputado Douglas Garcia estâo assentados em dinâmicas de diferenciaçáo e hierarquizaçáo interseccionais próprias da colonialidade (GROSFOGUEL, 2008). Esse modo de operaçâo, que racializa e subalterniza aquelas existências tomadas como inconformes, incongruentes em relaçâo à regulaçăo compulsória do gênero no sistema-mundo moderno/colonial de gênero pautado no dimorfismo biológico, na organizaçâo patriarcal e heterossexual das relaçóes sociais, segundo Lugones (2008), age também, argumento, a reboque da cisnormatividade, enquanto norma de identidades de gênero, "centrada na ideia de que gêneros săo binários (homem/mulher), pré-discursivos (definíveis objetivamente a partir dos corpos ou de sua 'essência') e permanentes ('năo fluidos', para ficar nos termos de modinha)" (VERGUEIRO, 2015, p. 195). É nesse ponto que reside a aposta central deste trabalho: focalizar os sentidos da colonialidade de gênero para além da

3 Neste trabalho, emprego a expressăo "pessoas trans" a fim de fazer referência a uma gama de experiências de gênero situadas em conflito com o imperativo transfóbico da coerência compulsória entre sexo e gênero, levando em conta o espectro de complexidades e intersecçôes indelimitáveis envolvidas nessas negociaçóes e seus agenciamentos políticos, a exemplo do vivenciado por pessoas autoidentificadas como travestis, transexuais, trangêneras, dentre muitas outras possibilidades. 
crítica de uma compreensăo relacional binária (homem X mulher) e da visăo dicotômica do desejo (heterossexualidade $\mathrm{X}$ homossexualidade), enfatizando os efeitos da "matriz de poder colonial" na produçâo da cisnormatividade e, consequentemente, da transfobia, a partir da análise de atos de fala transfóbicos, enquanto dimensâo simbólica constitutiva do padrâo de poder vigente no mundo eurocentrado.

Desse modo, o presente trabalho tem como objetivo propor desdobramentos em torno da compreensăo do funcionamento da violência linguística de motivaçăo transfóbica, tomando-a como parte do dispositivo de colonialidade de gênero em funcionamento na sociedade brasileira. Para tanto, recorro à discussăo dos dados gerados em uma pesquisa qualitativa de cunho etnográfico-virtual realizada por mim (SILVA, 2017), na seçăo de comentário do site de notícias G1, a partir da análise de atos de fala relativos a uma matéria jornalística que tematiza a crucificaçáo encenada pela modelo e atriz transexual Viviany Beleboni, durante a $19^{a}$ Parada do Orgulho LGBT de Săo Paulo, ocorrida em 2015. Assim, assumindo uma perspectiva radicalmente INdisciplinar em Linguística Aplicada (MOITA LOPES, 2006; FABRÍCIO, 2017), articulo construtos teóricos em torno das problemáticas da colonialidade/decolonialidade, como discutido pelo grupo Modernidade/Colonialidade (QUIJANO, 2005; LUGONES, 2008, 2014; MIGNOLO, 2008; GROSFOGUEL, 2008; MALDONADO-TORRES, 2011), das discussōes sobre performances de gênero, vivências trans, cisnormatividade e transfobia advindas dos estudos queer/cuir/transviados e transfeministas (VERGUEIRO, 2015; BUTLER, 2000, 2017; BENTO; PELÚCIO, 2012; BENTO, 2016; OLIVEIRA, 2017) e dos debates sobre atos de fala, performatividade, violência linguística, indexicalidade e entextualizaçấo, segundo perspectivas pragmáticas e socioantropológicas dos estudos da linguagem (AUSTIN, 1990; BUTLER, 1997; SILVA; ALENCAR, 2014; BAUMAN; BRIGGS, 2006; SILVERSTEIN, 2003; GUIMARĂES; MOITA LOPES, 2017)4.

\section{A TRANSFOBIA COMO DISPOSITIVO DA COLONIALIDADE DE GÊNERO}

Na esteira das discussóes encampadas por Vergueiro (2015), o argumento central das reflexóes propostas neste trabalho sustenta que a violência transfóbica, aqui considerada como expressăo de "uma matriz de crenças culturais e pessoais, opinióes e comportamentos agressivos, baseados no preconceito, nojo, medo e/ou ódio dirigido contra pessoas ou grupos que năo se conformam ou transgridem expectativas ou normas sociais de gênero" (TvT, 2019, s/p), encontra seu contexto mais remoto no interior de um projeto de dominaçăo e produçâo de subjetividades subalternizadas de ancoragem histórica no colonialismo. Tal termo diz respeito "ao processo e aos aparatos de domínio político e militar que se exercem para garantir a exploraçấo do trabalho e das riquezas das colônias em benefício do colonizador" (RESTREPO; ROJAS, 2010, p. 15). Superando as

4 Conforme sugerido pelas pessoas que avaliaram anonimamente este artigo, as quais agradeço pela revisâo criteriosa da versấo inicial deste texto, cumpre ressaltar que o fato de mobilizar construtos teóricos advindos também do pensamento de pesquisadoras e pesquisadores situados geograficamente na Europa ou nos Estados Unidos, a meu ver, náo deslegitima o compromisso aqui assumido com uma crítica decolonial das práticas de linguagem transfóbicas, uma vez que, do ponto de vista do discurso, estâo politicamente implicadas e implicados com uma produçâo epistemológica avessa aos processos de colonialidade, dominaçẫo e opressâo, segundo diferentes orientaçôes. 
limitaçōes temporais do fato histórico atinente às relaçôes coloniais formais, a exemplo do que se deu durante o período em que o Brasil esteve política e juridicamente sob domínio europeu, passo entăo a considerar os efeitos constitutivos do processo trans-histórico e multifacetado, de natureza epistêmica, política e ontológica, denominado como colonialidade, a saber:

um fenômeno histórico muito mais complexo que se estende até nosso presente, e que se refere a um padráo de poder que opera através da naturalizaçáo de hierarquias territoriais, raciais, culturais e epistêmicas que possibilitam a re-produçâo de relaçôes de dominaçăo; este padrăo de poder nâo só garante a exploraçăo pelo capital de alguns seres humanos por outros em escala mundial, como também a subalternizaçâo e obliteraçâo dos conhecimentos, experiências e formas de vida daquelas pessoas que săo assim dominadas e exploradas (RESTREPO; ROJAS, 2010, p. 15).

Nesse sentido, tomar a colonialidade enquanto um "padráo de poder" ou, ainda, como uma forma reiterada de exercício do poder na sociedade brasileira, pautado especialmente em relaçôes de hierarquizaçâo e dominaçáo, implica reconhecer a onipresença desses dois princípios em inúmeras instâncias e esferas da vida social no tempo presente, ainda que a partir de diferentes modos de operaçâo. Assim, tais modos capilarizados de funcionamento e seus efeitos de longa duraçâo, mediante incontáveis formas de continuaçăo histórica das relaçóes coloniais, especialmente no que concerne à produçâo de modos de subjetivaçấo específicos, ou seja, a produçấo de modos possíveis de ser sujeito, sugerem a centralidade da dimensâo simbólica das relaçôes de colonialidade, bem como sua relaçăo de imbricaçăo com outras facetas da questăo, a exemplo daquelas de natureza econômica e política.

Desse modo, "é necessário admitir que ainda existe um padrăo de poder global e um universo de representaçōes simbólicas fortemente enraizadas na larga história das relaçôes coloniais modernas, incluindo aqui, entre outros, o racismo, a escravidāo e o genocídio modernos" (MALDONADO-TORRES, 2011, s/p). Na esteira desses processos, agindo por meio de uma transfobia legitimada e naturalizada em boa parte das representaçôes simbólicas que sustentam a cultura brasileira, estâo os ditames patriarcais e sexistas de um ideário machista, sexista e heteronormativo, característico de naçóes resultantes de experiências coloniais, escravocratas, de bases cristăs e eurocentradas. Grosso modo, assim se caracteriza o processo histórico e social de "formaçâo" dos países da chamada América Latina e de seu posicionamento em relaçấo à Europa e às grandes naçôes colonizadoras, concebido mediante a dominaçăo năo apenas material e política, ou ao genocídio e ao etnocídio praticados em nome da "civilizaçăo", mas também centrada na inculcaçăo de determinados construtos ideológicos essenciais para a manutençâo das relaçôes de saber-poder colonizador-colonizado.

Tais construtos e seus "efeitos de verdade", no sentido foucaultiano do termo, forjaram o feixe de condiçōes a partir do qual sâo constituídas as "identidades nacionais" e os sentidos disponíveis na cultura para significar as formas de vida que se realizam em seu território geográfico e discursivo. Nesse contexto de possibilidades limitadas de subjetivaçáo, emergem também os significados sociais atribuídos aos corpos, aos gêneros e às sexualidades, em termos da replicaçăo, em contornos particulares e 
interseccionais ${ }^{5}$, a cada nova época situada, da rígida matriz identitária do colonizador, a qual é estabelecida como critério de hierarquizaçâo e (des)legitimaçăo das vidas e das subjetividades das pessoas colonizadas.

Seguindo essa direçâo, na busca pelo delineamento de uma genealogia crítica dos significados violentos atribuídos a experiências de gênero e sexualidade inconformes com essa referida matriz de inteligibilidade social (BUTLER, 2017), vejo nessa forma específica de violência, a violência transfóbica, uma manifestaçăo do poder colonial, o qual "afeta todas as dimensōes da existência social, tais como a sexualidade, a autoridade, a subjetividade e o trabalho" (GROSFOGUEL, 2008, p. 123). Assim, as multifacetadas formas de puniçấo e disciplinarizaçâo de corpos e performances de gênero e sexualidade dissidentes em relaçăo à suposta/imposta coerência entre sexo-gênero-desejo - as quais denunciam o caráter performativo de tais instâncias, enquanto efeito/produto e năo essência ou substância - sâo, em certo sentido, desdobramentos de práticas de regulaçăo da coerência de gênero (BUTLER, 2017). Esta, por sua vez, opera em funçăo da "normatividade cisgênera enquanto um conjunto de dispositivos de poder colonialistas sobre as diversidades corporais e de gênero, sendo tais dispositivos atravessados por outras formas de inferiorizaçăo, marginalizaçăo e colonizaçâo interseccionais" (VERGUEIRO, 2015, p. 72).

Assim, no que tange aos processos de reestabelecimento de contextos violentos que operam no bojo de atos de fala transfóbicos, o pensamento de Quijano (2005) oferece uma possibilidade de compreensâo sobre o modo como o processo de colonialidade está implicado na produçăo das subjetividades e, em funçâo disso, sobre a maneira pela qual o estabelecimento de padróes de gênero e sexualidades ditas normais/naturais está centrado na "colonizaçấo das perspectivas cognitivas, dos modos de produzir ou outorgar sentido aos resultados da experiência material ou intersubjetiva, do imaginário, do universo de relaçóes intersubjetivas do mundo; em suma, da cultura" (QUIJANO, 2005, p. 121).

Desse modo, para fins de uma visibilizaçâo das dinâmicas de poder que operam na produçâo e na subalternizaçâo de determinadas performances identitárias, sob o jugo dos ditames coloniais, a proposta de um pensamento decolonial está pautada no "descentramento das narrativas e dos sujeitos contemporâneos" (BALLESTRIN, 2013, p. 90), segundo uma tarefa de compreensáo das identificaçóes e dos fenômenos sociais segundo uma prática de desconstruçáo de essencialismos. Estes, por sua vez, pautados em binarismos constitutivos (colonizado/colonizador; civilizado/incivilizado; normal/ anormal; natureza/cultura; homem/mulher), operam no sentido de invisibilizar os agudos efeitos antropológicos e políticos do processo de colonialidade e do "sistema-mundo moderno-colonial" (QUIJANO, 2005), a exemplo da transfobia, sob o efeito performativo de discursos científicos, religiosos, médicos, religiosos, por exemplo, e dos efeitos de evidência de que estes gozam.

5 De modo geral, a interseccionalidade nos estudos de gênero propóe que a formaçâo de tal categoria está sempre imbricada com outros signos da vida social, como raça, etnia, classe, orientaçáo sexual, diversidade funcional, dentre outros, e que as performances de gênero sáo produzidas e significadas socialmente a partir do entrecruzamento dessas vertentes, bem como as diferentes formas de opressāo e violência advindas dessa sobreposiçáo de marcadores identitários. Para uma leitura mais detida sobre o tema, ler Carneiro (2003) e Crenshaw (1989, 2002). 
Sob o influxo dessas dinâmicas, sáo elaborados os marcos simbólicos de uma cartografia subjetiva que toma como parâmetro de normalidade-moralidade-aceitabilidade-viabilidade os modos de subjetivaçâo do colonizador. Por sua vez, segundo tal lógica, as experiências, os saberes, os desejos e os corpos dos sujeitos subjugados sâo significados sob o trânsito reiterado de atos de fala que projetam neles diferenças subalternizantes/racializantes, as quais, em última análise, efetuam a destituiçâo de sua condiçăo reconhecível de "humanidade". Como consequência desse processo, ficam justificadas diferentes modalidades de violência, praticadas a partir dos mais diversos quadros de poder - a exemplo do extermínio em massa, da escravizaçăo, da dominaçăo, da proletarizaçâo, do epistemicídio - daquele considerado “o Outro", situado mais além dos marcos do humano, em uma zona exterior/inferior dos ditos modos de vida válidos. Nessa regiăo, tanto simbólica quanto política, operam diferentes lógicas engajadas na produçáo de políticas de morte (MBEMBE, 2016) profundamente arraigadas nas dinâmicas sistemáticas, em termos de incidência e de crueldade, das mais variadas formas de violência.

Por esse prisma, epistemologias críticas às concepçôes dominantes de modernidade oferecem, a exemplo de perspectivas decoloniais e transfeministas ${ }^{6}$, caminhos $^{2}$ potentes com vistas a desnaturalizar as situaçôes de opressâo diversas, bem como os regimes semióticos dos atos de fala que as produzem, definidas a partir de fronteiras de raça, classe, gênero, orientaçăo sexual, diversidade funcional, dentre outros elementos. Desse modo, se posso compreender a violência transfóbica como prática disciplinar da cisheteronormatividade, como já discutido aqui, isso só me parece possível em funçâo de uma compreensâo mais ampla e profunda de sua implicaçấo nos processos de hierarquizaçăo e precarizaçâo de determinadas formas de vida em funcionamento nas dinâmicas de manutençăo das relaçóes de colonialidade de gênero, a partir da intersecçâo de diferentes marcadores sociais da diferença.

Segundo uma perspectiva que encara as relaçóes entre práticas de linguagem e vida social como mutuamente constitutivas, as dinâmicas políticas e simbólicas em funcionamento nos processos de colonialidade sâo sustentadas também em funçâo do caráter performativo do emprego situado de diferentes recursos semióticos. Assim, nos termos da perspectiva assumida neste artigo, compreendo que atos de fala transfóbicos, engajados em práticas de violência linguística, participam da elaboraçâo da multiforme condiçáo precária7 à qual sâo relegadas pessoas trans, na medida em que (re)produzem contextos que as interpelam a ocuparem năo-lugares, segundo uma geografia discursiva da vida que significa suas existências como ininteligíveis socialmente, relegando-as, desse modo, à condiçăo de abjeçăo (MISKOLCI, 2016). Dessa maneira, em funçāo das intensas atividades de categorizaçăo social que sustentam os processos de colonialidade, aqueles sujeitos significados dentro das normas de inteligibilidade

6 A opçâo que faço pela justaposiçăo desses dois termos, em separado, tem como objetivo enfatizar o caráter decolonial das políticas e epistemologias transfeministas, especialmente em face da desestabilizaçâo produzida pelos seus modos de agência, quer teóricos ou ativistas, sobre as certezas metafísicas em torno da delimitaçấo do sujeito político de um feminismo hegemônico cisnormativo, branco, burguês, eurocentrado e suas consequências transfóbicas, racistas e classistas.

7 Aqui, conforme sugere Butler (2004), compreendo que existem formas específicas e desiguais de distribuiçâo da vulnerabilidade que tornam determinados grupos populacionais mais passíveis de serem alvo da violência arbitrária do que outros. 
passam a "afirmar-se como uma identidade superior ao produzir construtos inferiores (raciais, nacionais, religiosos, sexuais, de gênero), e de expeli-los para fora da esfera normativa do 'real'"' (MIGNOLO, 2008, p. 291).

Em funçâo dessas articulaçôes, acredito que diferentes adensamentos de atos de fala engajados nas diversas práticas de linguagem, e nos significados eurocêntricos/ modernos/capitalistas/coloniais nelas produzidos, em termos de marcadores sociais da diferença, náo constituem um aspecto secundário ou derivado no projeto de uma analítica decolonial ou em uma investigaçáo crítica dos processos de colonialidade vigentes em diferentes âmbitos da vida social. Isso porque as dimensóes ideológicas da colonialidade, implicadas em um sem-número de práticas culturais e discursivas nas quais suas lógicas sâo reiteradas nâo correspondem meramente a elementos que se associam "às estruturas econômicas e políticas do sistema-mundo capitalista, mas [săo] sim uma parte integrante, entretecida e constitutiva desse amplo 'pacote enredado' a que se chama sistema-mundo patriarcal/capitalista/colonial/moderno/europeu" (GROSFOGUEL, 2008, p. 124).

Ademais, mediante o fato de tomar a transfobia como categoria contingente de estudo neste artigo, levando em conta os repertórios linguísticos empregados na sua constituiçâo, compreendo que sua análise deve levar a apreciaçóes mais profundas acerca da engenharia perversa de subalternizaçăo que realiza e legitima violências transfóbicas em nossa sociedade. Ou seja, o intento aqui posto ultrapassa uma mera catalogaçăo ou descriçăo higiênica, positivista, de atos de fala violentos em circulaçăo em espaços digitais de interaçấo ${ }^{8}$, o que poderia vir a reforçar o paradigma que póe corpos, identidades, perspectivas e experiências trans em lugares sempre sujeitos a explicaçōes, argumentaçōes, ou seja, permanentemente abertos à interpretaçáo alheia.

Nessa lógica criticável de um fazer que vê tais sujeitos como passíveis de análise, "os atributos cissexuais ${ }^{9}$ correspondentes săo simplesmente tomados como dados eles sâo tidos como 'naturais' e 'normais', escapando de análises recíprocas" (SERANO, 2007, s/p), corroborando uma ordem estigmatizadora em que os "discursos sobre transexualidade têm invariavelmente dependido de linguagem e conceitos inventados por pessoas médicas, pesquisadoras e acadêmicas que fizeram das pessoas transexuais seu objeto de estudo" (SERANO, 2007, s/p). Em certo sentido, tais práticas exercem uma forma de colonizaçăo epistêmica, uma vez que os saberes das pessoas trans, saberes subjugados, historicamente silenciados, só se tornam credíveis e legitimados mediante sua "traduçấo" e/ou "interpretaçâo" feita por pessoas, em geral, nâo trans, que, dotadas do capital simbólico e político de um título acadêmico, falam para seus pares, em geral, também pessoas năo trans, essas últimas, produzindo, por um lado, a cristalizaçâo das

8 Apesar de o material de análise explorado neste artigo nâo corresponder a uma definiçăo restritiva do que seja a interaçăo, no sentido de nos comentários em questăo nâo haver uma troca de turnos síncrona ou assíncrona entre dois ou mais interactantes, assumo aqui que toda prática linguística é, em alguma medida, interacional, uma vez que todo enunciado dialoga potencialmente com (responde a) outro(s) enunciado(s) presente(s), passado(s) ou futuro(s), conforme posto na ideia bakhtiniana de dialogismo (BAKHTIN, 2008), ainda que isso nâo seja materializado na alternância de turnos propriamente dita, especialmente a depender do gênero do discurso e do contexto em que a prática de linguagem ocorre.

9 Atributos relativos às experiências nas quais os sujeitos percebem a designaçâo sexual que lhe fora imposta ao nascimento, mediante discursos de instituiçôes médicas e familiares, como condizente com a identidade e/ou expressăo de gênero que aqueles desejam ou sentem que devem vivenciar. De modo geral, diz respeito aos atributos corporais, sexuais e de gênero daquelas pessoas autoidentificadas como năo trans. 
lógicas sociais que impedem que tais pessoas sejam produtoras de conhecimento e, por outro, um discurso marcado por certo exotismo de tom acadêmico.

Ao contrário do que uma leitura superficial desse argumento possa sugerir, năo se trata aqui de uma essencializaçáo identitária em torno de quem pode ou năo produzir conhecimento sobre questóes trans, como sugere uma leitura distorcida da potente ideia de "lugar de fala", mas do reconhecimento das epistemologias e das vozes de pessoas trans que já estăo engajadas, desde uma perspectiva politicamente radical, na produçáo de saberes, em suas diferentes modalidades e, no que tange às pessoas cisgêneras, em políticas de aliança (BUTLER, 2018) com essas, o reconhecimento de seus privilégios, a agência na busca pela democratizaçấo de espaços de poder e de produçấo do conhecimento e o reconhecimento da potência particular, para a urgente desestabilizaçăo de políticas identitárias e suas violências correlatas, de se colocar a normatividade/normalidade de gênero no lugar do escrutínio, da operaçăo crítica, da desnaturalizaçấo, a exemplo da política subversiva de produçăo transfeminista de categorias teóricas e analíticas como cisgeneridade e cisnormatividade.

Tendo argumentado em torno de uma interpretaçăo que considera a transfobia como parte do dispositivo da colonialidade de gênero vigente, na próxima seçăo apresentarei a dimensăo simbólica da manifestaçăo dessa violência, a violência linguística, desde uma visada pragmática e socioantropológica da linguagem.

\section{VIOLÊNCIA LINGUÍSTICA: PERFORMATIVIDADE, INDEXICALIDADE E ENTEXTUALIZAÇÃO DE DISCURSOS}

Parte da argumentaçăo sustentada neste trabalho acerca da dimensăo colonial da violência transfóbica perpetrada por determinados atos de fala está centrada em uma concepçáo performativa da linguagem. Ou seja, diferentemente de perspectivas representacionalistas, aqui a linguagem é concebida enquanto um modo particular de agência, uma forma de açáo situada de sujeitos engajados em contextos de uso específicos, por isso amplamente implicada em/por dimensóes sociohistóricas, políticas e ideológicas. Nesse sentido, mais que representar ou descrever, os usos de linguagem, em quaisquer de suas manifestaçôes semióticas, produzem performativamente a realidade que enunciam. Assim, "linguagem é um nome para nossa açấo: tanto o 'quê' fazemos (o nome para a açấo que caracteristicamente encenamos) e aquilo que fazemos acontecer, o ato e suas consequências" (BUTLER, 1997, p. 8).

Tal perspectiva, inaugurada pelo trabalho intelectual de Austin (1990) em torno dos atos de fala (speech acts) e com desenvolvimentos críticos substanciais nas obras de Butler (1997, 2017) e Derrida (1991), opera pela consideraçâo desnaturalizante de que os significados atribuídos às palavras năo sâo fruto de um dado interno aos sistemas da língua, qualquer que seja ela, enquanto racionalizaçăo lógica organizativa de signos, mas estes, os significados, emergem de seus contextos de uso. E aqui os contextos nâo sâo tomados enquanto cenas interacionais isoladas, fixas, nas quais sujeitos supostamente dotados de plena intencionalidade ${ }^{10}$ e racionalmente guiados interagem segundo seus

10 Para uma discussāo mais aprofundada sobre o problema da intencionalidade do sujeito na perspectiva dos atos de fala, ver Santos (2014). 
propósitos comunicativos absolutos. Diferentemente disso, nesta discussâo, os contextos săo entendidos enquanto "atos históricos e sociais onde dois ou mais agentes sociais interagem por meio da linguagem" (SILVA; ALENCAR, 2014, p. 260).

Desse horizonte, ao considerar a violência transfóbica exercida em determinadas práticas de linguagem, năo está em questăo um possível sentido violento inscrito em certos elementos do léxico ou o resultado do emprego de palavras dotadas, em si mesmas, de significado violento, conforme uma visăo imanentista da produçấo dos sentidos. Ao contrário, a relaçâo entre significaçāo e violência à qual faço referência diz respeito ao efeito ilocucionário ${ }^{11}$ produzido por determinados modos de açăo na linguagem, à violência que realizam determinados atos de fala, na medida em que evocam modos de açăo prévios ou ritualizaçóes (AUSTIN, 1990) contextuais relativamente estabilizadas e compartilhadas socialmente. Desse modo, cada ato de fala transfóbico proferido localmente em uma dada prática social de linguagem se inscreve "em outras redes de sentidos produzidas por outros atos de fala em outras atividades sociais específicas translocais e transtemporais" (SILVA, 2017, p. 48).

Tal dimensăo aponta para o fato de que "nomes injuriosos têm uma história, que é invocada e reconsolidada no momento da fala, mas năo é dita explicitamente" (BUTLER, 1997, p. 36), uma vez que náo se trata exatamente da história dos modos como esses nomes têm sido usados, mas da relativa estabilizaçăo e sedimentaçăo de seus usos, na medida em que eles passam a incorporar o próprio ato de fala enquanto "uma sedimentaçâo, uma repetiçâo que solidifica, que dá ao nome sua força" (BUTLER, 1997, p. 36). Em alguma medida, essa asserçăo sugere o fato de que a performatividade linguística năo deve ser compreendida como a realizaçâo de um ato isolado, singular ou deliberado, mas como resultado de uma prática insistente, reiterada e citacional ${ }^{12}$, graças a qual o discurso produz os efeitos que ele nomeia (BUTLER, 2000).

Assim, a violência linguística diz respeito ao efeito de determinados atos de fala que posicionam "o outro - especialmente aquele que representa a raça, o gênero, a sexualidade que năo se quer habitar - num lugar vulnerável que acaba por insultar, injuriar ou violar a sua condiçâo" (SILVA; ALENCAR, 2013, p. 135). Tomando tal definiçấo em relaçáo a algumas perspectivas já exploradas até aqui neste artigo, nâo me parece difícil pensar que, no decurso da atividade de posicionar contextualmente o outro por meio de atos de fala transfóbicos, emergem pistas de contextualizaçâo (GUMPERZ, 1982) que assinalam as dinâmicas dos significados sociais, culturais, políticos em jogo, os quais sâo reestabelecidos à medida que posicionam pessoas trans em contextos nos

11 Segundo a proposta de Austin (1990), os performativos possuem três dimensôes simultâneas e indissociáveis, a saber: ato locucionário - ato de dizer algo, produzir ruídos que formam vocábulos com certo sentido e referência mais ou menos definidos; ato ilocucionário - ato realizado "ao dizer algo", consiste em realizar atos como perguntar ou responder; dar uma informaçáo, ou garantia ou advertência; anunciar um veredito ou uma intençāo; pronunciar uma sentença; marcar um compromisso, entre outros; e ato perlocucionário - ato realizado "por dizer algo", consiste nos efeitos alcançados pelos atos de fala, como: convencer, comover, alarmar, obrigar, etc.

12 Conforme Derrida, "qualquer signo, linguístico ou năo-linguístico, falado ou escrito (no sentido corrente desta oposiçáo), em pequena ou grande unidade, pode ser citado, colocado entre aspas; com isso pode romper com todo contexto dado, engendrar infinitamente novos contextos, de forma absolutamente náo saturável. [...]. Esta citacionalidade, esta duplicaçáo ou duplicidade, esta iterabilidade da marca năo é um acidente ou uma anomalia, é aquilo (normal/anormal) sem o qual uma marca náo poderia mesmo ter funcionamento dito 'normal'" (DERRIDA, 1991, p. 25-26). 
quais a sua performance de gênero é, a reboque das lógicas do sistema mundo moderno/colonial, subalternizada ou encarada como abjeta.

Dito de outro modo, graças ao caráter indexical da linguagem (SILVERSTEIN; URBAN, 1996; SILVERSTEIN, 2003), ou seja, ao fato de que as formas linguísticas indexam, isto é, apontam para aspectos socioculturais compartilhados entre interlocutoras/es, através de dinâmicas simultâneas de pressuposiçăo e criaçăo de contextos ${ }^{13}$, tais pistas de contextualizaçăo funcionam no sentido de assinalar modos particulares de engajamento de determinados recursos semióticos, em funcionamento nos atos de fala, na "atribuiçâo de sentido-classificaçâo-valor (a signos, pessoas e situaçóes), e os consequentes efeitos sociais [...] relacionados à tipificaçăo de contextos e indivíduos como pertencentes a comunidades sociais identificáveis, grupos, categorias e posiçăo (idade, classe, raça, gênero, sexualidade etc.)" (FABRÍCIO, 2014, p. 149).

Graças a essa propriedade indexical inerente a todo signo, segundo a qual os elementos do "agora-dito remontam ao e de alguma forma incorporam ou ressoam o já-dito e chegam à frente, antecipam, e de alguma forma incorporam o a-ser-dito" (BAUMAN, 2005, p. 145), torna-se importante também atentar para o aspecto da mobilidade dos discursos e suas dinâmicas semióticas infinitas e sempre significativas (SILVERSTEIN, 2003) de entextualizaçáo/descontextualizaçăo/reentextualizaçáo (citaçăo). Segundo essa visada socioantropológica da linguagem, uma vez que um discurso assume a configuraçăo semiótica e comunicativa de um texto, ou seja, passa por um processo de entextualizaçăo, ele cumpre sua funçăo de "tornar o discurso passível de extraçăo, de transformar um trecho de uma produçaáo linguística em uma unidade - um texto - que pode ser extraído de seu cenário interacional. Um texto, entăo, nesta perspectiva, é discurso tornado passível de descontextualizaçăo" (BAUMAN; BRIGGS, 2006, p. 206).

Ademais, vale ressaltar que longe de ser esse um processo espontâneo ou mesmo năo-regulado, uma vez que os repertórios semióticos dos sujeitos, enquanto integrantes de grupos sociais específicos, sâo assimetricamente constituídos e valorados socialmente, "normatividades, sistemas de estratificaçăo e hierarquizaçōes entram em jogo, no modo como definimos sentidos válidos, criamos pertencimento e identificaçóes em sociedade" (GUIMARĂES; MOITA LOPES, 2017, p. 18). Conforme discute Blommaert (2010), nas atividades de entextualizar/descontextualizar/reentextualizar implicadas na circulaçăo dos discursos, os sujeitos se orientam segundo a coerçăo relativa das ordens de discurso ${ }^{14}$ (FOUCAULT, 2009), as quais funcionam em um certo domínio da atividade humana e em um momento específico da história.

13 Conforme discute Fabrício (2014, p. 149), "ao nos mover de concepçōes mais estáticas de contexto para a concepçấo deste como uma atividade constante, nấo restrita ao que acontece em situaçóes de comunicaçáo e encontros sociais específicos, compreendendo tanto a dimensâo interacional imediata em que se desenvolve a interpretaçấo das pistas de contextualizaçăo - e uma dimensấo mais translocal - em que as pistas e pressuposiçóes empregadas indicam repertórios históricos mais estáveis. Contextos sâo assim, pré-configurados, eles săo dialógica e reflexivamente engendrados através de práticas de contextualizaçăo (GUMPERZ, 1982), forjando espaços duradouros-mutantes, sempre em movimento".

14 Segundo Foucault (2009, p. 8), "em toda sociedade a produçăo do discurso é ao mesmo tempo controlada, selecionada, organizada e redistribuída por certo número de procedimentos que têm por funçáo conjurar seus poderes e perigos, dominar seu acontecimento aleatório, esquivar sua pesada e temível materialidade". 
Desse modo, cada vez que um discurso é entextualizado em novas práticas comunicativas, ele "pode muito bem incorporar aspectos do contexto, de tal forma que o texto resultante carregue elementos da história de seu uso consigo" (BAUMAN; BRIGGS, 2006, p. 206). Aplicando essa visăo aos objetivos de trabalho aqui assumidos, mediante a tarefa de produzir uma interpretaçăo decolonial da violência linguística praticada contra pessoas trans, é justamente a partir das pistas indexicais em funcionamento nos atos de fala transfóbicos analisados que será possível, em alguma medida, pressupor de que modo os contextos mobilizados (indexados) e os discursos entextualizados nessas interaçóes restabelecem sentidos da colonialidade de gênero que funcionam para ferir e subalternizar pessoas trans em funçăo de suas performances identitárias.

Com vistas a dar fôlego aos exercícios analíticos que compóem parte do trabalho relatado neste artigo, a exemplo do que tem sido feito por diferentes pessoas engajadas nos estudos da linguagem, a exemplo de Guimarăes e Moita Lopes (2017) e Melo e Moita Lopes (2015), lançarei máo, parcialmente, da proposta de Wortham (2001) no que concerne à classificaçăo das pistas indexicais. Apesar de reconhecer que em tal modelo as pistas sâo empregadas como instrumental analítico para narrativas produzidas em primeira pessoa, acredito que tal especificidade nâo significa uma restriçấo das possibilidades de sua aplicaçấ, haja vista a produtividade interpretativa produzida por tal construto em propostas que analisam práticas linguísticas outras, como atestam os trabalhos em Linguística Aplicada anteriormente referenciados. Notadamente, serăo úteis, neste artigo, as noçôes de referência, predicaçâo e citaçâo para tratar dos processos de indexicalidade nos atos de fala transfóbicos analisados, buscando, com isso, produzir um conhecimento contingente acerca do caráter situado de sua produçăo em práticas de linguagem, bem como de sua implicaçăo em ordens macrossociológicas, como eixo básico de sustentaçăo no nexo pragmática-metapragmática na circulaçăo dos discursos (SILVA, 2014).

Na seçăo seguinte, em funçăo das articulaçōes teórico-analíticas elaboradas em torno do funcionamento da violência linguística, mediante a consideraçâo de processos de entextualizaçấo e indexicalizaçâo de discursos, o trabalho analítico empreendido centrará esforços na produçăo de inteligibilidades acerca da mobilizaçâo de discursos da colonialidade de gênero nas práticas de violência linguística analisadas.

\section{ENTEXTUALIZAÇÃO E INDEXICALIDADE EM ATOS DE FALA TRANSFÓBICOS: DISCURSOS DE COLONIALIDADE DE GÊNERO}

Nesta seçâo, discuto os dados gerados originalmente em uma pesquisa qualitativa de caráter interpretativo (DENZIN; LINCOLN, 2006) e de inspiraçáo etnográfica virtual (HINE, 2002), desenvolvida por mim (SILVA, 2017), entre junho de 2016 e junho de 2017, na seçăo de comentários do maior site de notícias brasileiro, o G1. Visando a ampliar os desdobramentos teórico-analíticos emergentes nos estudos da linguagem acerca da violência linguística de motivaçâo transfóbica, analiso comentários online disparados pela repercussão midiática, em matérias jornalísticas, da performance da modelo e atriz transexual Viviany Beleboni, que encenou uma crucificaçâo na $19^{a}$ ediçâo da Parada do Orgulho LGBT de Săo Paulo, em 06 de junho de 2015, como mostra a Figura 1. 
Figura 1 - Imagem da performance da atriz Viviany Beleboni durante a 19a Parada do Orgulho LGBT de Sáo Paulo, divulgada pelo G1.

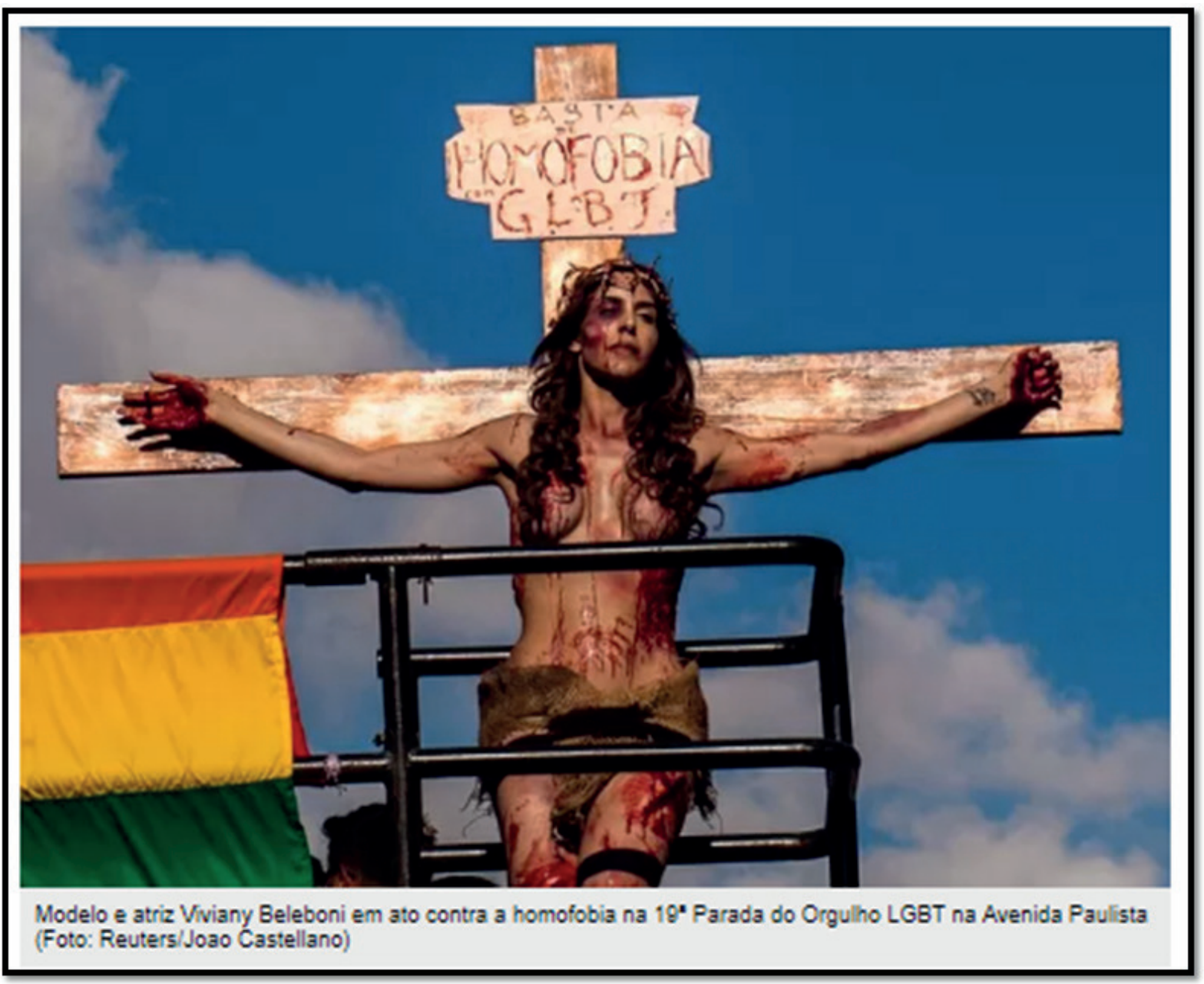

Fonte: Soares (2016).

Quanto ao critério de busca e seleçăo das matérias para a pesquisa, utilizei o sistema disponível na página do próprio site de notícias G1 (https://g1.globo.com/), mediante a inserçăo das palavras-chave TRANSEXUAL+ CRUCIFICADA + PARADA GAY. Por motivos de ausência de recursos de refinamento e de quantificaçâo de resultados de pesquisa na página em questăo, náo foi possível levantar, precisamente, quantos resultados a pesquisa com esse padrăo de busca forneceu, tampouco discernir se todas as matérias ali elencadas tratavam realmente do assunto do caso em questăo. Ademais, o site também náo oferecia resultados em ordem cronológica de publicaçăo e nem todas as matérias localizadas tinham comentários disponíveis para a visualizaçăo, por questōes técnicas do próprio site. Tais fatos, apesar de relevantes, năo comprometem os objetivos desta pesquisa, haja vista seu distanciamento de paradigmas quantitativistas ou fundados na busca de universais. 
Nas práticas de linguagem desencadeadas pela performance artística em questăo, as pistas de contextualizaçăo indexadas nos comentários online sugerem a entextualizaçăo de diferentes discursos que subalternizam e violentam pessoas trans, a exemplo de pistas indexicais que apontavam para a entextualizaçăo de discursos relativos à colonialidade, especificamente na sua faceta relativa às dimensóes de gênero. É a partir da interpretaçăo dos dados gerados em torno de dois comentários, dentre os 169 postados na matéria “Depoimento de transexual 'crucificada' sobre Parada Gay é adiado em SP", de autoria do jornalista Will Soares, publicada em 21 de junho de 2016, representada na Figura 2, que busco produzir inteligibilidades contingentes sobre o modo como a transfobia, desde sua faceta linguística, opera segundo o dispositivo da colonialidade de gênero.

Figura 2 - Matéria sobre o caso Viviany Beleboni no site de notícias G1, publicada em 21 de junho de 2016.

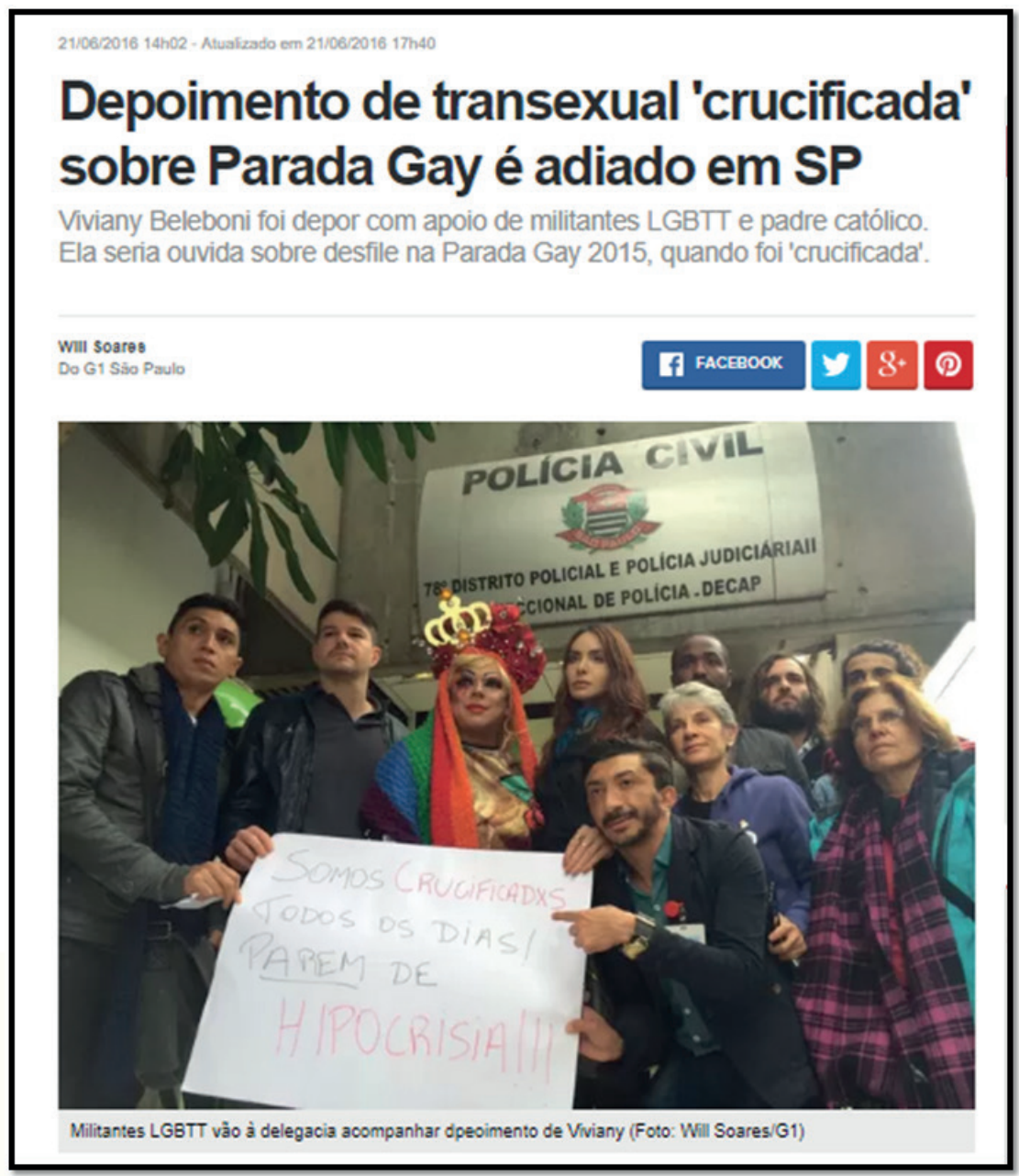

Fonte: Soares (2016).

A referida matéria relata o adiamento de um depoimento que Viviany Beleboni foi convocada a prestar, um ano depois de ocorrida a Parada LGBT, em razăo de ter sido denunciada pela Associaçăo de Igrejas Evangélicas de Săo Paulo, sob a acusaçâo 
de ter violado o artigo 208 do Código Penal Brasileiro, o qual versa sobre "escarnecer de alguém publicamente, por motivo de crença ou funçăo religiosa; impedir ou perturbar cerimônia ou prática de culto religioso; vilipendiar publicamente ato ou objeto de culto religioso" (BRASIL, 1984). Na ilustraçăo da matéria, ativistas LGBT e de direitos humanos que compareceram à delegacia no dia previsto para o depoimento, em protesto, seguram um cartaz com os dizeres "Somos crucificadxs todos os dias! Parem de hipocrisia!!!".

Apesar do número considerável de comentários online postados nessa matéria (169 comentários), vale salientar que nem todos eles se configuravam como passíveis desta análise, uma vez que o foco de investigaçăo delineado aqui recai sobre aqueles que recorriam a discursos transfóbicos. Em alguns comentários apareciam de forma recorrente manifestaçôes de insatisfaçấo com o feito ou de desaprovaçăo com a causa LGBT, mas, em última análise, năo chegavam a constituir atos de violência que tomassem como alvo de ataques a performance de gênero, ou, em alguns casos, a presumida orientaçâo sexual da atriz, entextualizando discursos nos quais opera a colonialidade de gênero, como o comentário registrado na Figura 3.

Figura 3 - Comentário de Max Lopes à matéria do G1.

\section{Max Lopez}

HÁ 2 ANOS

Pois é, a sociedade tem que se mobilizar logo ou o país vai perder os valores e a chance de reverter isso. Falta mais o que para que o povo entenda que a erotização e sexualização precoce de crianças é um programa de governo? É pra isso que querem inserir a Ideologia de Gênero nas escolas privadas e públicas, querem corromper transformarem as crianças a partir dos berçários. Nossos filhos tem o direito de crescer de acordo com a ordem natural das coisas sem serem doutrinados com ideias nefastas. Pior de tudo é ver tudo isso sendo patrocinado pelo dinheiro publico.

\section{$1691916 \cdot$ if}

Fonte: Soares (2016).

Em uma proposta de revisâo e ampliaçâo do conceito de "colonialidade do poder" (QUIJANO, 2005), com vistas à elaboraçăo de uma crítica às hierarquizaçōes de identidades de gênero produzidas pela matriz cisnormativa eurocêntrica, Lugones propóe a ideia de "colonialidade de gênero" como sendo também "um eixo organizador da sociedade ao criar categorias opostas de homem e mulher, na qual a última se submete ao primeiro, como um legado da colonizaçăo" (2008, p. 88). Nesse sentido, a matriz de gênero vigente, para além das relaçôes binárias entre as categorias homem e mulher, estabelece a cisgeneridade como norma de inteligibilidade social, exercendo sobre 
corpos e identidades trans diversas formas de violência, a fim de "afirmar-se como uma identidade superior ao construir construtos inferiores (raciais, nacionais, religiosos, sexuais, de gênero), e de expeli-los para fora da esfera normativa do 'real'" (MIGNOLO, 2008, p. 291).

Nesse sentido, a violência transfóbica assume um caráter de colonialidade, ou melhor, esta funciona como um dispositivo ${ }^{15}$ multifacetado que visa a exercer o "poder que opera através da naturalizaçăo de hierarquias territoriais, raciais, culturais e epistêmicas [e de gênero] que possibilitam a reproduçáo [inclusive na linguagem] de relaçôes de dominaçấo" (RESPRETO; ROJAS, 2010, p. 15). Desse modo, como vemos a partir dos contextos produzidos no ato de fala registrado na Figura 3, dentro de um ideário da colonialidade de gênero, "decisôes regulamentares, leis, medidas administrativas" (FOUCAULT, 2000, p. 244), bem como outros elementos relativos ao poder colonial e, por isso, normalizador do Estado, săo invocados para exercer a violência contra identificaçôes lidas como inconformes às normas compulsórias de gênero.

Ainda nesse comentário, os processos de referência e predicaçâo indexam discursos nos quais săo estabelecidas relaçōes pautadas em binarismos excludentes próprios dos dispositivos de colonialidade, como é o caso da transfobia. De um lado, aqueles sujeitos que, por estarem dentro das normas de gênero inteligíveis segundo o projeto de naçáo colonial (a cisgeneridade compulsória), săo posicionados contextualmente dentro da sociedade e, em diâmetro oposto, aqueles que, por se constituírem como sujeitos em conflito com tais normas, insurgindo-se contra os dispositivos de colonialidade, săo situados em uma zona marginal à sociedade, como abjetos, como náo-cidadăos.

Nesse sentido, é possível ver como a violência transfóbica na linguagem opera por meio da produçấo de posiçóes contextuais que agem no sentido de construir e hierarquizar performances identitárias. Assim, seguindo a dinâmica da colonialidade de gênero produzida na Figura 3, as pistas inscritas nos processos de referência indexam discursos sobre uma cartografia social na qual os sujeitos conformes com a matriz cisnormativa, lugar sociodiscursivo onde o comentador situa a si mesmo para produzir tal ato de fala transfóbico, săo designados como "a sociedade", "o país", "o povo" - aqueles em conformidade com "os valores". Dessa visada, o comentador assume discursivamente o lugar do colonizador, aquele cuja identidade (tomada pela lógica colonial como correta, saudável, civilizada, moralmente aceitável, outorgada por Deus) é parâmetro para inferiorizar, marginalizar e colonizar as identidades significadas por ele como dissidentes e, por isso, inferiores.

Já no que diz respeito aos recursos semióticos de natureza discursivo-interacional empregados pelo comentador Max Lopes para a construçáo da referência às experiências trans no seu discurso, essa se realiza sem recorrer a nomeaçóes diretas, sendo elaborada pelo emprego de itens linguísticos de caráter demonstrativo, mais canônicos para a construçăo da referência a objetos ("reverter isso"; "tudo isso"). Nesse contexto, os sentidos da colonialidade em funcionamento agem sob o influxo das forças de despersonalizaçâo do "Outro", daquele sujeito a quem se quer colonizar. Uma vez posicionado

15 “Um conjunto decididamente heterogêneo que engloba discursos, instituiçōes, organizaçōes arquitetônicas, decisóes regulamentares, leis, medidas administrativas, enunciados científicos, proposiçôes filosóficas, morais, filantrópicas. Em suma, o dito e o năo dito sāo os elementos do dispositivo. O dispositivo é a rede que se pode tecer entre estes elementos" (FOUCAULT, 2000, p. 244). 
fora da "sociedade", em uma regiăo de conflito com seus "valores" (cisnormativos), ele é potencialmente inominável, irrepresentável dada a sua condiçăo de năo-humanidade. Nesse sentido, ao enunciar as experiências trans em posiçâo oposta à sua, gerando pistas indexicais de caráter predicativo, como em "ideias nefastas", "perder valores", "erotizaçâo e sexualizaçâo das crianças", é indexicalizado o "discurso transfóbico [que] encontra ressonância em valores morais amplamente arraigados na nossa sociedade. Um discurso que busca identificar e controlar pessoas entendidas como 'perversas', 'manipuladoras', de 'falsa identidade'" (GRIM, 2015, s/p. apud VERGUEIRO, 2015, p. 70).

Assim, segundo tais discursos, para efetuar a colonizaçăo dessas identidades incivilizadas, a "catequese" dessas almas pagás e a dominaçăo desses corpos "bárbaros", em defesa "da sociedade", "do país", "do povo", "dos valores", faz-se necessário chegar a uma sociedade de polícia, controlada por dispositivos de segurança. Mas segurança de quê/de quem? Cabe, em tal lógica da colonialidade de gênero, referida inclusive pelo poder jurídico e de polícia do Estado, invocar um arsenal diversificado de estratégias institucionais de segurança para manter a salvo (do poder transgressor e desnaturalizador das experiências trans) o efeito de verdade e de homogeneidade em torno da cisgeneridade como norma única de vida viável, ou seja, para manter a salvo políticas de reconhecimento centradas na cisnormativdade.

Desse modo, o emprego de formas linguísticas indexicais como "é pra isso que querem inserir a ideologia de gênero" para se referir a um suposto modo de agência das pessoas trans ou do movimento LGBT nas "escolas públicas e privadas" aponta para discursos transfóbicos e conservadores em franca circulaçăo na sociedade brasileira, especificamente em funçăo do crescente pânico moral (JUNQUEIRA, 2017) registrado frente à relativa crise de modos de subjetivaçăo (e de representaçăo cultural) tradicionais em termos de gênero e sexualidade, bem como de instituiçóes diretamente ligadas a esses processos, a exemplo do dito modelo tradicional de família, pautado na cisgeneridade, na heterossexualidade, na monogamia e na heteroparentalidade.

Nesse sentido, tais pistas indexicais fazem precipitar um discurso "forjado para operar como uma arma política, enquanto dispositivo retórico, metadiscursivo, paródico e reacionário". Ele, por um lado, "age para conter ou anular o potencial crítico e emancipador do feminismo e dos estudos de Gênero e deslegitimar atores e reinvindicaçóes neles fundamentados" e, por outro, "enseja a valorizaçăo, o acúmulo e a recuperaçăo de capital social e político por parte dos setores tradicionalistas e ultraconservadores", a exemplo de grupos religiosos hegemônicos os quais desejam exercer seu poder "inclusive em temas e espaços năo estritamente religiosos ou que, em sociedades laicas, năo deveriam ser religiosos, como a educaçăo e a saúde pública" (JUNQUEIRA, 2017, p. 56).

Para além do já posto, os processos de referência e predicaçăo, a exemplo dos registrados em "nossos filhos têm o direito de crescer segundo a ordem natural das coisas sem serem doutrinadas com ideias nefastas", indexicalizam discursos calcados em uma compreensăo essencialista e biologizante das experiências de gênero, a qual sustenta o "dimorfismo entre homens e mulheres baseando essa argumentaçăo na observaçăo e referendando-a nas ciências biológicas, como aquelas que já ofereceram provas indiscutíveis da radical diferença sexual que separa os corpos sexuados" (BENTO; PELÚCIO, 2012, p. 575). A violência produzida pela consideraçâo das experiências trans como 
sendo patológicas é decorrente da assunçăo desse quadro normativo transfóbico de referência, uma vez que dissidentes em relaçăo à natural/saudável diferenciaçăo entre homens e mulheres, "reforçando circularmente a diferença sexual natural, subsumindo nessas 'verdades' os aspectos culturais e simbólicos que constituem nossas percepçōes sobre corpos, gêneros, órgāos e fluidos" (BENTO; PELÚCIO, 2012, p. 575).

Tal argumentaçăo justifica, dentre outras formas de violência colonial pautadas em uma suposta "normalidade de gênero", a subjugaçấo das corporalidades e subjetividades travestis, transexuais, trangêneras e outras em conflito com a cisnormatividade, à tutela do saber-poder médico em funcionamento nas categorias nosológicas (relativas à classificaçấo das patologias), nas decorrentes possibilidades, indefinidamente em debate, de descriçăo e de cura da suposta doença (referenciada como transtorno/ disforia/incongruência) nos laudos periciais que "atestam" essa identidade patologizada como passaporte para uma existência medicalizada, aparentemente a única relativamente viável, e para a vivência de uma cidadania permanentemente precária. Ou ainda, conforme discute Beatriz Bagagli (2016, p. 97), nessas perspectivas transfóbicas, "a verdade do gênero é dita, na patologizaçăo, através de lógicas específicas que concebem [o] gênero como uma categoria nosológica. A patologizaçăo orienta as formas com que a verdade sobre as identidades dos sujeitos pode ser conhecida (no caso, diagnosticada)".

Nesse sentido, considerando a ordem dos discursos criminalizadores e patologizantes em funcionamento na violência linguística motivada pela transfobia, săo salientes os "atravessamentos sociais, culturais, identitários, semióticos e de circulaçâo, típicos dos processos comunicativos contemporâneos" (GUIMARĂES; MOITA LOPES, 2017, p. 13). Assim, tais atravessamentos, quando dimensionados em face da natureza indexical da linguagem, apontam para discursos a partir dos quais pessoas trans săo significadas em atos de fala violentos, segundo uma lógica colonial, atualizando e reiterando o fato de que "o patriarcado europeu e as noçóes europeias de sexualidade [...] foram exportadas para o resto do mundo através da expansâo colonial, transformadas assim nos critérios hegemónicos que iriam racializar, classificar e patologizar a restante populaçăo mundial de acordo com uma hierarquia de raças superiores e inferiores" (GROSFOGUEL, 2008, p. 124). Desse modo, no funcionamento dos sentidos coloniais, aqueles sujeitos significados em face desses processos de racializaçáo estâo, ainda, submetidos a estratégias de disciplinarizaçāo e ao exercício de diferentes formas de autoridade engajadas no controle de suas existências, a exemplo do que faz o comentário registrado na Figura 4. 
Figura 4 - Comentário de Aureliano Gomes à matéria do G1.

\section{Aureliano Gomes}

HÁ 2 ANOS

\section{MP onde estão vocês agora??? O cidadão "Viviany Beleboni" vai ficar} IMPUNE???

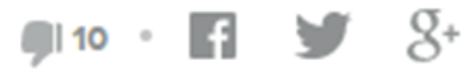

Fonte: http://g1.globo.com/sao-paulo/noticia/2016/06/depoimento-de-transexual-crucificada-sobre-parada-gay-e-adiado-em-sp.html. Acesso em: 22 abr. 2019.

No comentário de Aureliano Gomes, os sentidos de um policiamento ontológico e normativo que almeja invisibilizar identidades de gênero dissidentes, tarefa cuja funçâo é estruturante para a manutenção das relaçóes de colonialidade, emergem de pistas indexicais de referência, a exemplo de " $\mathrm{MP}$ " (forma corrente no Brasil para referir-se ao Ministério Público), o qual é conclamado a agir em defesa da sociedade (estruturada pela transfobia), a fim de punir "o cidadâo [sic] 'Viviany Beleboni"', forma usada pelo comentador para se referir à transexual, posicionando-a contextualmente, no curso desse ato de fala, como transgressora de determinadas normas e, por isso, passível de puniçấo. Aqui, conforme aponta Grim, "pessoas [...] sem essa identificaçấo e controle [...] estariam livres para exercer todo tipo de abusos, violências e degeneraçóes. [...] É o discurso do Estado. É o discurso do policiamento" (GRIM, 2015, s/p. apud VERGUEIRO, 2015, p. 70, grifo meu).

Nessa direçâo, pensando que a funçâo do Ministério Público é, grosso modo, "fiscalizar o cumprimento das leis que defendem o patrimônio nacional e os interesses sociais e individuais [...]"16, os sentidos produzidos pelas pistas indexicais em análise apontam para as relaçōes estabelecidas entre o "poder público", o "cumprimento da lei", a "defesa do patrimônio nacional" e "dos interesses sociais e individuais" e a violência transfóbica como instrumento de normalizaçăo e perpetuaçăo da aparência de estabilidade do gênero evocada como funçāo do Estado na manutençâo de uma "ordem pública cisheteronormativa", como têm demonstrado os estudos de Pérez Navarro (2017, 2018). Nesse sentido, o efeito da aparente estabilidade normativa é pautado na suposta e "impositiva linearidade entre sexo, gênero e desejo, que estabelece a cis/ heterossexualidade compulsória", conforme também discutem Sofia Fávero e Joâo Gabriel Maracci (2018, p. 29).

Tal direçáo interpretativa ganha particular substância ao se considerar a gama de violências que o poder institucional legitimado no Brasil historicamente exerce contra

16 Conforme disponível em: http://www.pge.sp.gov.br/centrodeestudos/bibliotecavirtual/presos/parte5.htm. Acesso em: 22 jun. 2017. 
pessoas trans, especialmente em funçâo da precariedade do reconhecimento estatal de seu direito à identidade e à autodeterminaçấo ${ }^{17}$. É indexando discursos relativos a esse tipo de violência, inclusive sob o recurso discursivo-interacional da manipulaçâo do sistema de gênero gramatical (BORBA; OSTERMANN, 2007) e do recurso às aspas, que o comentador, ainda no ato de fala presente na Figura 4, refere e predica Viviany Beleboni como "o cidadâo 'Viviany Beleboni"'. Tais pistas indexicais tanto realizam na linguagem o năo reconhecimento da performance identitária desempenhada pela atriz quanto negociam sua cidadania.

Nessa gestăo política da identidade na linguagem, a condiçâo de cidadania lhe é oferecida estrategicamente nesse momento, a fim de, inclusive por meio dela, efetuar a violência contra sua identidade de gênero. Assim, como alguém designado homem ao nascimento, em razăo do poder performativo do discurso médico, reiterado na cultura, ou seja, como "cidadăo", no masculino compulsório, como "o cidadâo [sic] Viviany Beleboni", ela pertenceria à "sociedade", "ao povo", "à naçấo" - conforme a hierarquia identitária produzida no ato de fala analisado na Figura 3-mas, como mulher trans, cuja identidade é construída em conflito com a cisnormatividade compulsória, esse direito lhe é interditado, tendo entăo seu corpo e sua identidade relegados à ininteligibilidade (BUTLER, 2017) e à inviabilidade (SILVA, 2017). Desse modo, parece acontecer também na linguagem um tipo de violência que integra o cotidiano de inúmeras pessoas trans que enfrentam diariamente os efeitos de políticas de identidade estatais pautadas em ontologias fixas - violentas e excludentes. Frente a isso, recorrem à transgressăo e a modos de agência pautados na inflexăo com vistas a reivindicar seus nomes e suas existências como cidadâs, implementando, para tanto, estratégias micropolíticas de resistência queer/cuir/transviadas (SILVA, 2019) na busca por significados para suas vidas que nâo lhes sejam impostos sob a égide da colonialidade de gênero, quer pela patologizaçăo, quer pela gestâo perversa de uma cidadania precária e violenta.

Ainda no comentário registrado na Figura 4, ocorre a entextualizaçâo de um discurso centrado em significados sociais que tomam as pessoas trans como passíveis de puniçâo em face de sua "desobediência de gênero" (OLIVEIRA, 2017), de modo que o comentador invoca/convoca o Estado, especificamente em sua faceta penal/penalizadora, sob o discurso da impunidade, com vistas a infligir algum tipo de castigo normalizador e disciplinador ao corpo e à existência de Viviany Beleboni, metonimicamente referindo-se às pessoas trans como tipos reconhecíveis de sujeitos. Nesse sentido, a violência linguística operada por esse ato de fala indexicaliza discursos nos quais "os corpos das pessoas trans ainda sofrem de uma colonizaçăo por parte das normas de gênero e do modelo biomédico" (OLIVEIRA, 2017, p. 32), experimentando como puniçấo limítrofe a

17 No Brasil, somente a partir de 2018, as pessoas trans tiverem seu direito de retificar nome e "sexo" em seus registros civis reconhecido pelo Estado, sem necessidade de laudos psiquiátricos patologizantes. Vale ressaltar que tal conquista, apesar de histórica e de grande relevância para a populaçăo trans, ainda é marcada por certa precariedade, especialmente pelo fato de ter sido obtida junto ao Supremo Tribunal Federal, mediante julgamento de matéria de Repercussăo Geral e năo mediante um processo social e democrático, emanado da representaçâo popular nas casas legislativas e sendo tornado, assim, lei, a exemplo do que ocorreu na Argentina com a Lei de Identidade de Gênero. Dessa cidadania precária advêm entraves para a efetivaçáo de uma cidadania global, a exemplo da ausência de políticas públicas transespecíficas para que esse direito ao nome tenha repercussôes em serviços públicos de saúde e educaçấo, por exemplo. Tal dinâmica é uma tendência para a conquista de direitos de grupos dissidentes de gênero e sexualidade no Brasil, haja vista o caráter conservador e fundamentalista religioso tanto da Assembleia Legislativa quanto do Senado Federal. 
sua eliminaçăo exemplar e ritualmente cruel, como nos casos de transfeminicídio.

A respeito desse caráter punitivo e disciplinar do assassinato de mulheres trans, Bento (2016, p. 51) diz que "a funçăo social do transfeminicídio é a espetacularizaçâo exemplar. Os corpos desfigurados importam na medida em que contribuem para a coesăo e a reproduçáo da lei de gênero que define que somos o que nossas genitálias determinam". E prossegue: "da mesma forma que a sociedade precisa de modelos exemplares, de heróis, os náo exemplares, os párias, os seres abjetos também sâo estruturantes para o modelo de sujeitos que năo devem habitar a Naçăo". Enfim, a violência transfóbica, em todas as suas formas de manifestaçâo, inclusive linguística, atua também no sentido de cumprir essa funçâo de produzir uma condiçâo de vulnerabilidade e de exposiçăo à puniçăo e ao castigo para as performances de gênero tidas como năo-exemplares e, em contrapartida, uma condiçăo de segurança ontológica e privilégio para as performances de gênero exemplares, porque em coerência com uma matriz de gênero pautada pela cisnormatividade, conforme os ditames da colonialidade de gênero.

Buscando assentar as palavras finais deste percurso de reflexăo, na seçăo seguinte, última deste artigo, sintetizo em três consideraçóes os elementos centrais da argumentaçâo realizada em torno das relaçôes entre transfobia, colonialidade de gênero e violência linguística, acenando, ainda, para algumas implicaçōes éticas, por um lado, das práticas de linguagem violentas, em relaçấo ao modo como elas significam sujeitos dissidentes e, por outro, das pesquisas em Linguística Aplicada que intencionem produzir uma interpretaçăo da vida social contemporânea na sua relaçăo com aquilo que fazemos diariamente com/pela/na linguagem, especialmente na sua relaçăo com o problema da violência.

\section{O QUE AINDA HÁ POR DIZER}

Em decorrência da trajetória epistemológica percorrida neste artigo, penso que seja possível, enfim, elencar alguns pontos centrais que podem ser encarados, de algum modo, como extrato do caminho de articulaçăo teórica e de análise trilhado, o qual, certamente, possui um caráter situado e parcial (MOITA LOPES, 2006), nem de longe almejando uma posiçâo de irrefutabilidade, fixidez ou universalidade. Assim, acredito ser possível considerar que

i. a violência transfóbica, inclusive em sua faceta linguística, pode ser compreendida como parte do dispositivo de colonialidade de gênero. Tal dispositivo, que assenta seu horizonte simbólico em marcos de reconhecimento eurocentrados, significa como năo-humanos, abjetos e, por isso, violentáveis, matáveis, sujeitos que performam vivências de gênero e sexualidade em desacordo com ontologias fundadas na suposta coerência compulsória entre sexo, gênero e desejo;

ii. significados violentos nâo sâo exatamente resultados de propriedades linguísticas imanentes aos signos ou aos sistemas linguísticos enquanto produtos de uma racionalizaçăo lógica e essencialista sobre a linguagem. Em vez disso, sâo efeitos produzidos por atos de fala engajados na (re)produçáo de contextos específicos, mediante seu caráter performativo e indexical, na medida em que citam/iteram outros atos de fala violentos proferidos em outros contextos 
translocais e transtemporais, em uma dinâmica contínua de entextualizaçăo, descontextualizaçăo e recontextualizaçâo própria da mobilidade de recursos semióticos descentráveis, os textos, recuperáveis entre eventos interacionais;

iii. os contextos reinstaurados por atos de fala em circulaçăo passam a assumir particular relevância na compreensâo da violência linguística, enquanto instâncias dinamicamente produzidas em situaçōes de interaçăo graças aos processos contínuos de modelagem, ampliaçáo/limitaçâo de sentidos, implementados de acordo com os horizontes de possibilidades dos sujeitos nas posiçôes assumidas por eles em determinadas atividades sociais/discursos. Em resumo, a força ilocucionária dos atos de fala transfóbicos advém do processo de atualizaçăo e reestabelecimento de contextos implementados por tais proferimentos.

De forma geral, tais consideraçôes abrem espaço para reflexôes em torno da problemática da esfera ética instaurada pelo engajamento em práticas de linguagem e, de forma específica, naquelas práticas cuja linguagem exerce um tipo de açăo violenta. Certamente tais perspectivas ganham particular relevância em tempos de acirramento de disputas sociais nos mais variados espaços públicos, inclusive naqueles de caráter virtual, e de intensificaçăo de discursos de ódio e intolerância motivados por diferentes manifestaçōes de fascismo social (SOUSA SANTOS, 2016) e suas violentas hierarquias existenciais, pautadas por diferentes formas de significaçăo do outro como inferior. Também em razáo disso, no que concerne a fazer pesquisa aplicada nos domínios da linguagem, levantam-se questóes relativas às consequências éticas do exame crítico desse tipo de práticas de linguagem, especialmente em face da problematizaçăo de aspectos relativos ao que os esforços interpretativos dos trabalhos analíticos permitem dimensionar em termos de sujeitos sociais e instituiçóes que agenciam os discursos entextualizados nas práticas de violência.

Como consequência da argumentaçăo sustentada neste artigo, o desafio da construçâo de uma ética do dizer contrária aos fascismos sociais vigentes, especialmente no que diz respeito à produçăo de sentidos em torno de pessoas dissidentes em termos de gênero e sexualidade, a exemplo das pessoas trans, está relacionado com um compromisso queer/cuir decolonial, especialmente em funçấo do reconhecimento de que a "colonizaçăo de corpos e gêneros inconformes à cisnormatividade remonta a processos genocidas e racistas [que] nos posiciona[m] [...] diante do desafio constante de ampliar as frentes de lutas decoloniais" (VERGUEIRO, 2015, p. 34). Tal compromisso, em alguma medida, é pautado pela desnaturalização de significados transfóbicos produzidos em práticas de violência linguística, a qual incide sobre a instância semiótica do dispositivo de colonialidade de gênero e de seus marcos simbólicos de classificaçâo/ racializaçâo do humano. Assim, penso que está incluída na demanda urgente pela afirmaçăo de um projeto de democracia radical, protagonizado por povos em vias de decolonizaçăo, a ampla e diversificada crítica à cisnormatividade como instrumento de violência colonial, como princípio organizador da sociedade em funçâo da legitimaçâo do gênero enquanto índice de opressâo e das consequentes políticas desiguais de distribuiçăo populacional da morte, inclusive em face dos efeitos performativos dos regimes linguísticos de significaçâo. 


\section{REFERÊNCIAS}

AUSTIN, J. L. Quando dizer é fazer. Traduçăo Danilo Marcondes de Souza Filho. Porto Alegre: Artes Médicas, 1990.

BAGAGLI, B. P. A diferença trans no gênero para além da patologizaçăo. Periódicus, Salvador, v. 1, n. 5, p. 87-100, maio/out. 2016.

BAKHTIN, M. Problemas da poética de Dostoiévski. Traduçāo Paulo Bezerra. 4. ed. Rio de Janeiro: Forense Universitária, 2008.

BALLESTRIN, L. América Latina e o giro decolonial. Revista Brasileira de Ciência Política, n. 11, p. 89-117, maio/ago. 2013.

BAUMAN, R. Commentary: indirect indexicality, identity, performance: dialogic observations. Journal of Linguistic Anthropology, v. 15, n. 1, p. 145-150, 2005.

BAUMAN, R.; BRIGGS, C. Poética e performance como perspectivas críticas sobre a linguagem e a vida social. Ilha, v. 8, n. 1.2, p. 185-271, 2006.

BENTO, B. Transfeminicídio: violências de gênero e o gênero da violência. In: COLLING, L. (Org.) Dissidências sexuais e de gênero. Salvador: Edufba, 2016. p. 43-68.

BENTO, B.; PELÚCIO, L. Despatologizaçăo do gênero: a politizaçăo das identidades abjetas. Estudos Feministas, v. 20, n. 2, p. 559-568, 2012.

BLOMMAERT, J. The sociolinguistics of globalization. Cambridge: University Press, 2010.

BORBA, R.; OSTERMANN, A. C. Do bodies matter? Travestis' embodiment of (trans)gender identity through the manipulation of the Brazilian Portuguese grammatical gender system. Language and Gender, v. 1, n. 1, p. 131-147, 2007.

BOURDIEU, P. Linguagem e poder simbólico. Traduçăo Fernando Tomaz. Saao Paulo: Difusāo Editorial, 1989.

BUTLER, J. Corpos em aliança e a política das ruas: notas para uma teoria performativa da assembleia. Rio de Janeiro: Civilizaçăo Brasileira, 2018.

BUTLER, J. Corpos que pesam: sobre os limites discursivos do "sexo". Trad. Thomas Tadeu da Silva. In: LOURO, G. L. O corpo educado: pedagogias da sexualidade. Belo Horizonte: Autêntica, 2000.

BUTLER, J. Lenguaje, poder e identidad. Madrid: Síntesis, 1997. 
BUTLER, J. Precarious life. London: Verso, 2004.

BUTLER, J. Problemas de gênero: feminismo e subversăo da identidade. Traduçăo Renato Aguiar. Rio de Janeiro: Civilizaçăo Brasileira, 2017.

BRASIL. [CP 1984]. Código Penal Brasileiro. Rio de Janeiro: Saraiva Jur. 4 ed. 2019.

CARNEIRO, S. Enegrecer o feminismo: a situaçăo da mulher negra na América Latina a partir de uma perspectiva de gênero. In: ASHOKA EMPREENDENDORES SOCIAIS; TAKANO CIDADANIA (Orgs.). Racismos contemporâneos. Rio de Janeiro: Takano Editora, 2003.

CRENSHAW, K. Demarginalizing the intersection of Race na Sex: A Black Feminist Critique of Antidiscrimation doctrine, feminist theory and racist politics. Disponível em: https://goo.gl/KfTSp. Acesso em: 09 jan. 2019.

CRENSHAW, K. Documento para o encontro de especialistas em aspectos da discriminaçâo racial relativos ao gênero. Revista de Estudos Feministas, ano 10, jan./jul., 2002.

DENZIN, N. K.; LINCOLN, Y. S. O planejamento da pesquisa qualitativa: teorias e abordagens. Traduçăo Sandra Regina Netz. Porto Alegre: Artmed, 2006.

DERRIDA, J. Assinatura, acontecimento, contexto. In: DERRIDA, J. Margens da filosofia. Tradução Joaquim Torres Costa, Antônio M. Magalhăes. Campinas: Papirus, 1991. p. 349-373.

FABRÍCIO, B. F. Linguística aplicada e visāo de linguagem: por uma INdisciplinaridade radical. Revista Brasileira de Linguística Aplicada, Belo Horizonte, v. 17, n. 4, p. 599-617, 2017.

FABRÍCIO, B. F. Transcontextos educacionais: gêneros, sexualidades e trajetórias de socializaçăo na escola. In: SILVA, D. N.; FERREIRA, D. N. M.; ALENCAR, C. N. (Orgs.). Nova Pragmática: modos de Fazer. Sáo Paulo: Cortez, 2014. p. 145-189.

FÁVERO, S. R.; MARACCI, J. G. Transfake e a busca pela verdade na representaçáo de travestis e pessoas trans. Revista Brasileira de Estudos da Homocultura, v. 1, n. 04, p. 18-39, fev. 2019.

FOUCAULT, M. A ordem do discurso. Traduçâao Laura Fraga de Almeida Sampaio. Săo Paulo: Ediçōes Loyola, 2009.

FOUCAULT, M. Microfísica do poder. Rio de Janeiro: Graal, 2000. p. 69-78. 
GARCIA, D. Transcriçăo parcial do áudio do vídeo Deputada Erica Malunguinho vai abrir processo contra o deputado Douglas Garcia (PSL). Disponível em: https://www.facebook. com/watch/?v=591546678021412. Acesso em: 04 abr. 2019.

GRIMM, E. Pra pensar em que trans.feminismos tamos pilhando pra 2015. 2015. Disponível em: https://www.facebook.com/permalink.php?story Łfbid=153556799673 0102\&id=10000830748133. Transmodernidade, pensamento de fronteira e colonialidade global. Revista Crítica de Ciências Sociais, n. 80, p. 115-147, mar. 2008.

GROSFOGUEL, R. Para descolonizar os estudos de economia política e os estudos pós-coloniais: Transmodernidade, pensamento de fronteira e colonialidade global. Revista Crítica de Ciências Sociais, v. 80, p. 115-147, mar. 2008.

GUIMARĀES, T. F.; MOITA LOPES, L. P. Trajetória de um texto viral em diferentes eventos comunicativos: entextualizaçâo, indexicalidade, performances identitárias e etnografia. Alfa, Săo Paulo, 61 (1), p. 11-33, 2017.

GUMPERZ, J. Discourse strategies. Cambridge: Cambridge University Press, 1982.

HINE, C. Virtual Ethnography. London: Sage Publications, 2002.

JUNQUEIRA, R. D. Ideologia de gênero: um dispositivo retórico de ofensiva antifeminista. In: DIAS, A. F.; SANTOS, E. F.; CRUZ, Maria H. S. (Orgs.). Gênero e sexualidades: entre invençōes e desarticulaçōes. Aracaju: Editora IFS, 2017.

LUGONES, M. Colonialidad y Género. Tabula Rasa, Bogotá - Colombia, n. 9, p. 73-101, jul.-dez., 2008.

LUGONES, M. Rumo a um feminismo descolonial. Estudos Feministas, Florianópolis, v. 22, n. 3, p. 935-952, set./dez. 2014.

MALDONADO-TORRES, N. Con Fanon ayer y hoy. 2011. Disponível em: http://www.decolonialtranslation.com/espanol/con-fanon-ayer-y-hoy.html. Acesso em: 23 abr. 2019.

MBEMBE, A. Necropolítica. Artes \& Ensaios, n. 32, p. 123-151, dez. 2016.

MELO, G.; MOITA LOPES, L. P. “Você é uma morena muito bonita”: a trajetória textual de um elogio que fere. Trabalhos em Linguística Aplicada, Campinas, v. 1, n. 54, p. 53-78, jan./jun. 2015.

MIGNOLO, W. Desobediência epistêmica: a opçâo descolonial e o significado de identidade em política. Cadernos de Letras da UFF, Rio de Janeiro, Dossiê: Literatura, língua e identidade, n. 34, p. 287-324, 2008. 
MISKOLCI, R. Teoria Queer: um aprendizado pela diferença. Belo Horizonte: Autêntica Editora, 2016.

MOITA LOPES, L. P. (Org.). Por uma Linguística Aplicada Indisciplinar. Săo Paulo: Parábola Editorial, 2006.

MOITA LOPES, L. P. (Org.). Linguística Aplicada e vida contemporânea: problematizaçăo dos construtos que têm orientado a pesquisa. In: . (Org.). Por uma Linguística Aplicada Indisciplinar. Săo Paulo: Parábola Editorial, 2014. p. 84-105.

OLIVEIRA, J. M. Desobediências de gênero. Salvador: Editora Devires, 2017.

QUIJANO, A. Colonialidade do poder, eurocentrismo e América Latina. In: LANDER, E. (Org.). A colonialidade do saber: eurocentrismo e ciências sociais: perspectivas latino-americanas. Buenos Aires: CLACSO, 2005. p. 227-278.

PÉREZ NAVARRO, P. Márgenes de la ley: epifenômenos de violência biopolítica. Cadernos Pagu, n. 52, p. 68-93, 2018.

PÉREZ NAVARRO, P. Cisheteromonormatividad y orden público. In: OLIVEIRA, J. M.; AMÂNCIO, L. (Eds.). Géneros e sexualidades: intersecçōes e tangentes. Lisboa: CIS-IUL. p. 89-113.

RESTREPO, E.; ROJAS, A. Inflexión decolonial: fuentes, conceptos y cuestionamientos. Popayán, Colombia: Editorial Universidad del Cauca, 2010.

SANTOS, K. C. Implicaçōes da noçăo de sujeito na discussăo da responsabilidade da fala. In: SILVA, D. N.; FERREIRA, D. M. N.; ALENCAR, C. N. (Orgs.). Nova pragmática: modos de fazer. Campinas: Cortez, 2014. p. 287-307.

SĂO PAULO. [PL 346/2019]. Projeto de Lei n³46/2019. Sáo Paulo: Assembleia Legislativa do Estado de Sáo Paulo, 2019.

SERANO, J. Whipping Girl: a transsexual woman on sexism and the scapegoating of femininity. Emeryville, Califórnia: Seal Press, 2007.

SILVA, D. C. P. Atos de fala transfóbicos no ciberespaço: uma análise pragmática da violência linguística. 2017. 200f. Dissertaçâo (Mestrado em Letras) - Programa de PósGraduaçâo em Letras, Universidade Federal de Sergipe, Săo Cristóvâo, 2017.

SILVA, D. C. P. Micropolíticas de resistência queer na narrativa de uma professora de educaçâo básica. Humanidades e Inovaçāo, v. 6, n. 10, p. 89-105, 2019. 
SILVA, D. N. O texto entre a entextualizaçăo e a etnografia: um programa jornalístico sobre belezas subalternas e suas múltiplas recontextualizaçōes. Linguagem em (Dis) curso, Tubaráo, n. 14, p. 67-84, 2014.

SILVA, D. N. ; ALENCAR, C. N. A propósito da violência na linguagem. Cadernos de Estudos Linguísticos, v. 55, n. 2, p. 129-146, 2013.

SILVA, D. N. ; ALENCAR, C. N. A Violência e significaçăo: uma perspectiva pragmática. In: ; FERREIRA, D. M. N.; ALENCAR, C. N. (Orgs). Nova Pragmática: modos de fazer. Săo Paulo: Cortez, 2014. p. 259-285.

SILVERSTEIN, M. Indexical order and dialectics of sociolinguistic life. Language $\&$ Communication, University of Chicago, n. 23, p. 193-229, 2003.

SILVERSTEIN, M. URBAN, G. (Eds.). Natural histories of discourse. Chicago: The University of Chicago Press, 1996.

SOARES, W. Depoimento de transexual crucificada sobre Parada Gay é adiado em Săo Paulo. G1 São Paulo. 2016. Disponível em: http://g1.globo.com/sao-paulo/noticia/2016/06/depoimento-de-transexual-crucificada-sobre-parada-gay-e-adiado-em-sp.html. Acesso em: 22 abr. 2019.

SOUSA SANTOS, B. A difícil reinvençâo da democracia frente ao fascismo social. 2016. Disponível em: http://www.ihu.unisinos.br/159-noticias/entrevistas/563035. Entrevista concedida a Ricardo Machado. Acesso em: 23 abr. 2019

TRANSPHOBIA VS TRASRESPECT (TvT). Terminology: Transphobia. 2019. Disponível em: https://transrespect.org/en/working-definitions/. Acesso em: 09 jul. 2019.

VERGUEIRO, V. S. Por inflexóes decoloniais de corpos e identidades de gênero inconformes: uma análise autoetnográfica da cisgeneridade como normatividade., 2015. 244f. Dissertaçăo (Mestrado em Cultura e Sociedade) - Programa Multidisciplinar de PósGraduaçâo em Cultura e Sociedade da Universidade Federal da Bahia, Salvador, 2015.

WORTHAM, S. Narratives in action. New York: Teacher College Press, 2001. 